\title{
INFLUENCE OF CASTING PARAMETERS ON FATIGUE PROPERTIES OF THE ŻS6U-WI ALLOY
}

\begin{abstract}
The hot parts of aircraft engines are made of nickel-based superalloys and work in extremely difficult conditions. The compressor blades mentioned in the article are usually produced by a casting process whose parameters have a great influence on the fatigue properties of the end product. The parameters of the casting process have significant influence on the microstructure, i.e. phase components morphologies. The article presents the results of the analysis of microstructures of nickel superalloys and the influence of casting parameters on the fatigue strength of finished products. The casting parameters were selected experimentally. The work included analysis of the microstructure of semifinished products and high-cyclic fatigue strength tests of the final product.
\end{abstract}

Keywords: ŻS6U-WI, fatigue properties, compressor turbine blades.

\section{Introduction}

The determination of the fatigue limit is important for defining safe engine life. Technological procedures may affect the fatigue properties of the final product. Moreover, modern aviation, in order to reduce the consumption of materials used in the construction of machines, requires the use of either high-strength materials, and resistant to cyclic stresses associated with their operation. The analysis of the causes of failure of aircraft machinery and their equipment elements shows that $90 \%$ of all reported fractures are caused by the fatigue process [1].

Nickel-based superalloys are classic materials used in the aerospace industry. Their wide application is related to the possibility of operation at high temperatures, their high creep resistance, fatigue and resistance to aggressive atmosphere [2]. The many advantages of nickel-based alloys show that without these versatile materials, the aerospace industry would have a hard time finding a replacement alloy. Parts used in aviation production are primarily exposed to high temperatures (even up to approx. $900^{\circ} \mathrm{C}$ in the case of compressor turbine blades), variable mechanical loads and the aggressive environment of oxidizing gases. The ŻS6U-WI material is a creep-resistant, induction vacuum melted casting alloy intended for remelting in vacuum induction furnaces during casting, among others, vanes and other complex-shape parts. This alloy is usually supplied as cast bar

\footnotetext{
1 Anna Tomczak; Faculty of Mechanical Engineering and Aeronautics, Rzeszow University of Technology, al. Powstańców Warszawy 12, 35-959 Rzeszów, Poland; Pratt \& Whitney Rzeszów, Rzeszów, Poland, e-mail: anna.tomczak@prattwhitney.com
} 
blanks (called masterheats) vary in diameter and length sizes. ŻS6U-WI is a nickel superalloy with a high percentage of such elements as chromium, cobalt, tungsten or aluminum. Table 1 shows the exact chemical composition of the alloy based on the industry standard OST-1-90126-85.

The hot parts of aircraft engines are often produced in the casting process, such as the compressor blades described in the publication. Improving the mechanical and physical properties of casting alloys through modification old and introduction of new technological methods as well as a constant increase in the efficiency of the processes used - completely change the production capabilities of modern foundry. The introduction of new engine designs forces the continuous modification of casting materials, models, ceramic molds, as well as the parameters of the melting, casting and heat treatment processes. It is important to identify the influence of casting parameters on the final properties of the manufactured part. The factors significantly affecting the casting properties are the pouring temperature, the solidification rate of the casting and the use of modifiers. The improvement of the structure of the nickel-based superalloy can be achieved by appropriate shaping, among others, grain size during the casting process. Controlled grain size can be achieved by a specific pouring temperature, mold temperature and the use of a modifier in the mold surface layer. The literature data shows that the pouring temperature has the strongest impact on the macrostructure of individual casting zones. The use of low pouring temperature is associated with obtaining large grains and columnar grains. The use of a higher pouring temperature eliminates this phenomenon. The use, i.e. overheating of the material, favors the formation of grains of uncontrolled size and shape. It is important that the casting temperature is optimally selected taking into account the use of the part.

For the research covered by the publication, $1^{\text {st }}$ stage compressor turbine blades were used. The turbine is the basic assembly of an aviation turbine engine. It is a rotating flow machine, which is used to extract energy from a flowing fluid to provide mechanical energy in the form of shaft work by changing the enthalpy, pressure and velocity of the working fluid. This work determines the power developed by the turbine, the receivers of which are min. turbine engine compressor, airplane propellers, helicopter rotors and engine accessories. The design of the drive turbine greatly influences the performance of the turbine engine. Increasing the efficiency of the turbine results in an increase in thrust / power and a reduction in the specific fuel consumption of the engine (and vice versa). The operational reliability of a turbine engine depends on the geometry of individual components making up the turbine, which are subjected to high thermal and mechanical loads (in particular blades). Turbine engine blades are elements through which the energy of the medium is transferred to the rotor. Blades can certainly be considered the most important elements of the engine, as the safety of the entire system depends on their strength and durability. The experience of many years shows that the destruction of the blades during operation is not only the cause of damage to the engine itself, but sometimes the plane [3]. 
Table 1. The chemical composition of the ŻS6U-WI alloy, \%.

\begin{tabular}{|c|c|c|}
\hline Element & Min & Max \\
\hline $\mathrm{C}$ & 0,13 & 0,20 \\
\hline $\mathrm{Cr}$ & 8,0 & 9,5 \\
\hline $\mathrm{Co}$ & 9,0 & 10,5 \\
\hline $\mathrm{Mo}$ & 1,2 & 2,4 \\
\hline $\mathrm{V}$ & 9,5 & 11,0 \\
\hline $\mathrm{Al}$ & 5,1 & 6,0 \\
\hline $\mathrm{Ti}$ & 2,0 & 2,9 \\
\hline $\mathrm{Nb}$ & 0,8 & 1,2 \\
\hline $\mathrm{S}$ & - & 0,4 \\
\hline $\mathrm{Mg}$ & - & 0,4 \\
\hline $\mathrm{Ni}$ & \multicolumn{2}{|c|}{ matrix } \\
\hline
\end{tabular}

\section{Experiments}

The article analyzes the influence of casting parameters on the result of testing the high-cycle fatigue strength of the final product. The parameters of the casting process were selected experimentally based on the range of standards for the ŻS6U-WI material. The casting process was performed on a production Balzers WSG 25 vacuum furnace using the investment casting process with application of parameters presented in the table 2 .

The results of the casting process influence on the microstructure and the properties of the fatigue strength of the finished product will be analyzed. Thus, the subject of the research was to produce the samples in the form of finished products of the 1st Stage Compressor Turbine Blades used in aviation production. Thus, casted samples ( 9 samples per melt) were then subjected to:

- Heat treatment at the temperature of $1220^{\circ} \mathrm{C}$.

- Machining of the lock and blade blades.

- Diffusion aluminization.

* detailed parameters of the casting process are shown in Table 2.

Table 2. Parameters of the casting process of three experimental heats of the ŻS6U-WI alloy.

\begin{tabular}{|c|c|c|c|c|c|}
\hline $\begin{array}{c}\text { Melt } \\
\mathrm{nr}\end{array}$ & $\begin{array}{c}\text { Casting } \\
\text { mold } \mathrm{nr}\end{array}$ & $\begin{array}{c}\text { Time in } \\
\text { a vacuum }[\mathrm{s}]\end{array}$ & $\begin{array}{c}\text { Casting temperature } \\
{\left[{ }^{\circ} \mathrm{C}\right]}\end{array}$ & $\begin{array}{c}\text { Mold temperature } \\
{\left[{ }^{\circ} \mathrm{C}\right]}\end{array}$ & $\begin{array}{c}\text { Modifier } \\
(\text { cobaltaluminate }) \\
{[\%]}\end{array}$ \\
\hline 1 & $1 \div 9$ & 30 & 1535 & & \\
\cline { 2 - 4 } 2 & $1 \div 9$ & 180 & $1534 \div 1536$ & \multirow{2}{*}{1000} & \multirow{2}{*}{10} \\
\cline { 2 - 4 } 3 & Fix.1 & 180 & 1535 & \\
\cline { 2 - 4 } 3 & Fix.2 2 & 30 & 1535 & \\
\hline
\end{tabular}


The research was carried out on samples from one masterheat that underwent the same cycle of mechanical and thermal processes, and then the following tests were carried out:

- Fatigue tests - The blades for fatigue tests were mounted in a holder on the electrodynamic exciter table and excited to resonant vibrations with the first bent form. The stress level, measured at the strain gauge sticking point, was kept constant during the test. The fatigue strength tests were carried out using the crack method. $\mathrm{N}=1 \cdot 10^{7}$ cycles was adopted as the base number of cycles. The stress level for each blade was increased stepwise by o $\Delta \sigma=2\left[\mathrm{kG} / \mathrm{mm}^{2}\right]$, until the tested blade cracked. For each melt, the conventional strength limit and the average fatigue strength were calculated. A compressor turbine blade with a strain gauge is shown in Figure 1. The results of fatigue tests are presented in tables 4 to 6 .

Table 3. Inductor LDS V721 Shaker specification

\begin{tabular}{|c|c|c|c|c|c|c|c|c|c|}
\hline Model & $\begin{array}{c}\text { Sine } \\
\text { Force } \\
\text { (peak) }\end{array}$ & $\begin{array}{c}\text { Ran- } \\
\text { dom } \\
\text { Force } \\
\text { (RMS) }\end{array}$ & $\begin{array}{c}\text { Half- } \\
\text { sine } \\
\text { Shock } \\
\text { Force }\end{array}$ & $\begin{array}{c}\text { Veloc- } \\
\text { ity } \\
\text { (sine } \\
\text { peak) }\end{array}$ & $\begin{array}{c}\text { Accel- } \\
\text { eration } \\
\text { (sine } \\
\text { peak) }\end{array}$ & $\begin{array}{c}\text { Accel- } \\
\text { eration } \\
\text { Ran- } \\
\text { dom } \\
\text { (RMS }\end{array}$ & $\begin{array}{c}\text { Dis- } \\
\text { place- } \\
\text { ment } \\
\text { (peak- } \\
\text { peak) }\end{array}$ & $\begin{array}{c}\text { Usable } \\
\text { Fuency } \\
\text { Range }\end{array}$ & Max Payload \\
\hline $\begin{array}{c}\text { LDS V721 } \\
\text { Shaker + }\end{array}$ & & & & & & & & \\
$\begin{array}{c}\text { LPA1000 } \\
\text { Linear Power } \\
\text { Amplifier + } \\
\text { FPS Field } \\
\text { Power Supply }\end{array}$ & $\begin{array}{c}2,9 \\
{[\mathrm{kN}]}\end{array}$ & $\begin{array}{c}1,9 \\
{[\mathrm{kN}]}\end{array}$ & $\begin{array}{c}4,6 \\
{[\mathrm{kN}]}\end{array}$ & $\begin{array}{c}0,70 \\
{[\mathrm{~m} / \mathrm{s}]}\end{array}$ & $\begin{array}{c}650 \\
{\left[\mathrm{~m} / \mathrm{s}^{2}\right]} \\
(66,3 \mathrm{~g})\end{array}$ & $\begin{array}{c}440 \\
{\left[\mathrm{~m} / \mathrm{s}^{2}\right]}\end{array}$ & $\begin{array}{c}25,4 \\
{[\mathrm{~mm}]}\end{array}$ & $\begin{array}{c}\text { DC to } \\
4000 \mathrm{~Hz}\end{array}$ & $\begin{array}{c}\mathrm{Up} \text { to } 100 \\
{[\mathrm{~kg}]}\end{array}$ \\
\hline
\end{tabular}

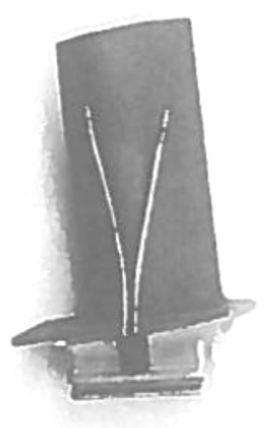

Fig. 1. A compressor turbine blade with a strain gauge sensor

- Metallographic observations - performed using the Nikon Epiphot 300 light microscope (LM) and the Hitachi S-3400N scanning electron microscope (SEM) - a voltage of $20 \mathrm{kV}$ was used, a secondary electron (SE) detector. Observations of the microstructure were carried out on specimens made with standard methods with the use of Struers devices according to ASTM E3, in the non-etched and digested condition with Kalling reagent. 
The diagram of metallographic sampling is shown in figure 2 . The scheme symbols are presented according to the following markings: $\boldsymbol{T L}-$ Top left, $\boldsymbol{T R}-$ Top Right, BL - Botton left, BR - Botton right, $\boldsymbol{C}$-Center, $\boldsymbol{T}-$ Top, $\boldsymbol{B}-$ Botton.
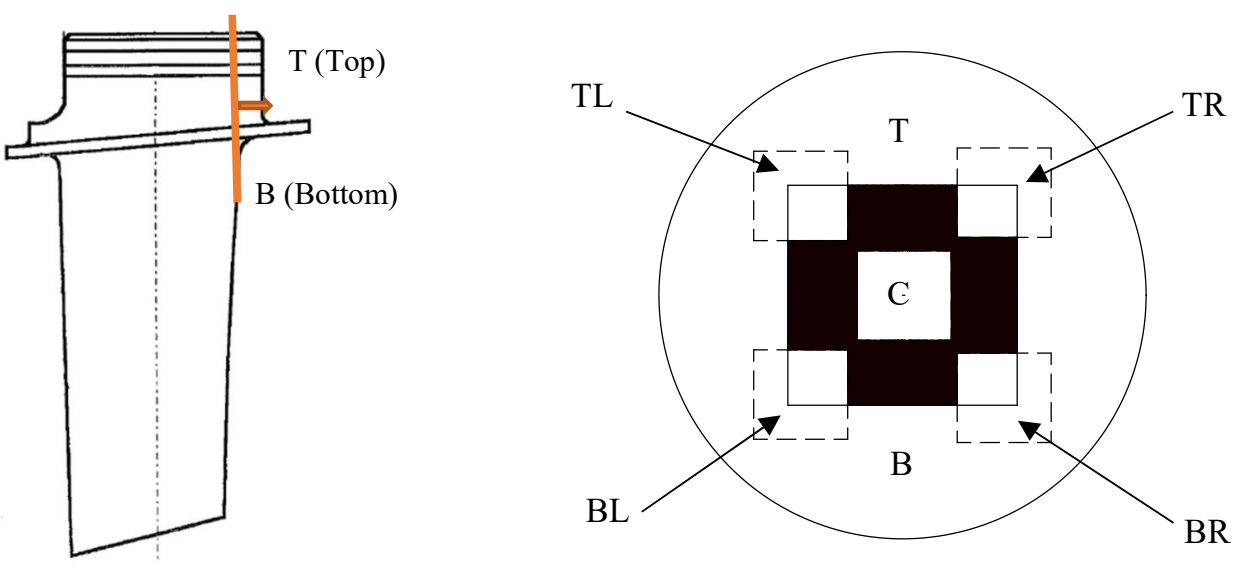

Fig. 2. Scheme of zones subjected to microstructure tests

The microstructure was assessed on transverse metallographic specimens made from the area of the lock of the blades in the place indicated in Figure 2. The cutting direction and the place of sampling are shown in figure 2. The photos of the microstructure shown in figures 3 to 5 are described according to the abovementioned markings.

\section{Results and discussion}

The selected areas showing the microstructure of the ZS6U-WI alloy according to the cutting scheme given in Figure 2.

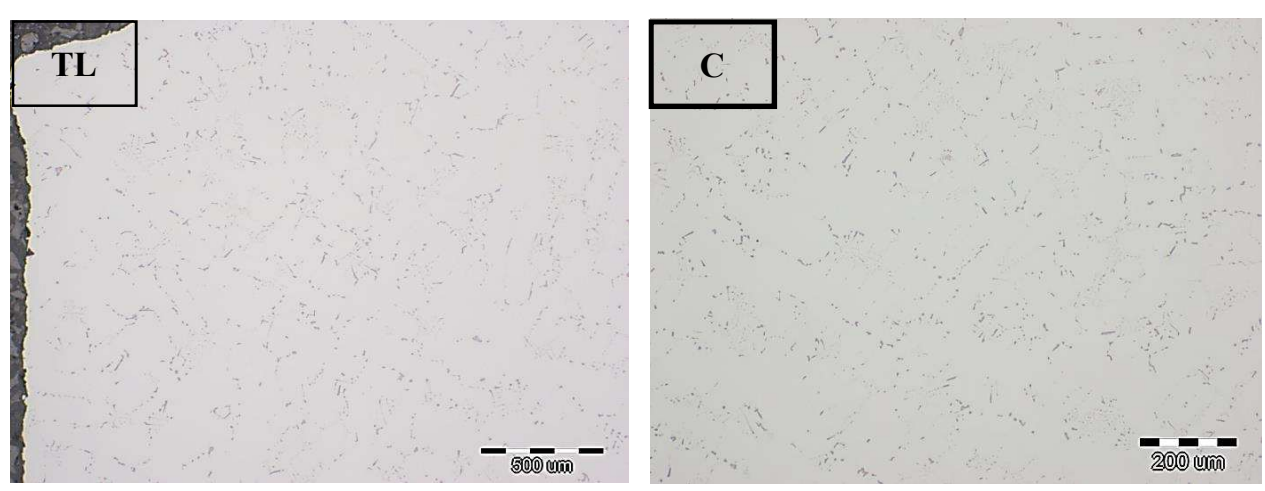

Fig. 3. ŻS6U-WI alloy. Microstructure of melt number 1, non-etched condition, LM. 


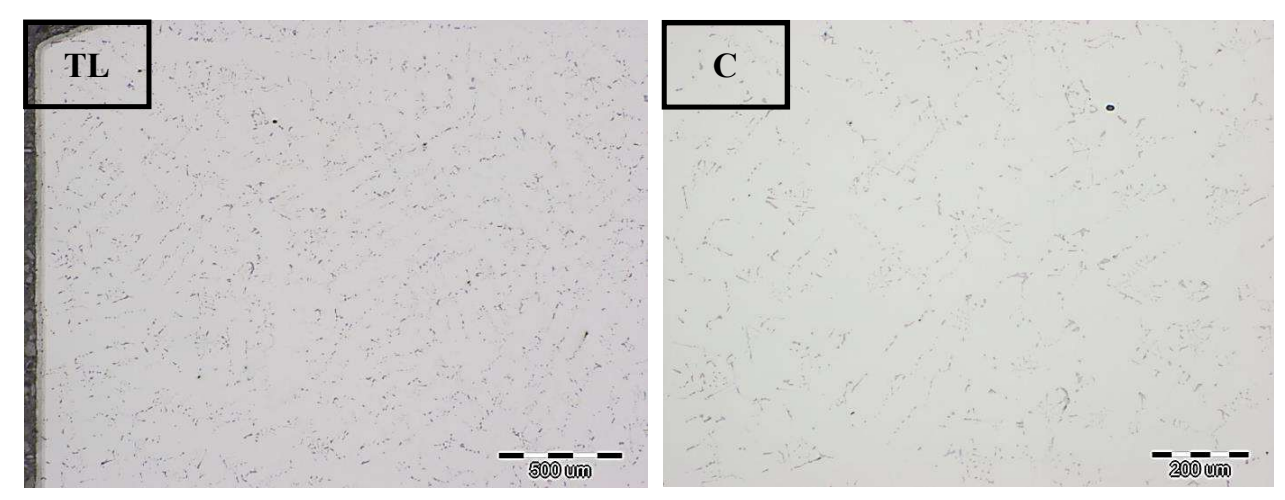

Fig. 4. Superalloy ŻS6U-WI Melt microstructure. 2 mat. ŻS6U-WI, non-etched condition, LM.
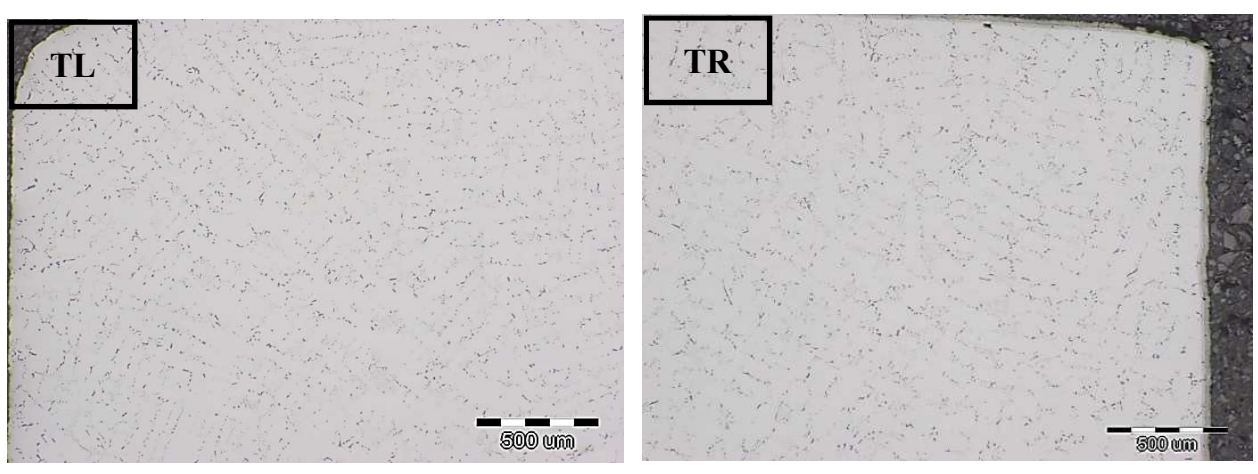

Fig. 5. ŻS6U-WI alloy. Microstructure of melt number 3, ŻS6U-WI alloy, non-etched condition, LM.

Based on the observation of the microstructure, it was found that it is typical for a nickel foundry alloy of the ŻS6U-WI alloy. It is characterized by the matrix - y phase (solid solution of alloying elements in nickel), dispersion strengthening phase $\mathrm{y}^{\prime}-\mathrm{Ni}_{3}(\mathrm{Al}, \mathrm{Ti})$ and carbides of $\mathrm{MC}$ and $\mathrm{M}_{23} C_{6}$ type placed in the matrix. Carbides are precipitating mainly in dendritic spaces and partially at the grain boundaries, they have various shapes and sizes. Inside the grains, the presence of the $y-y^{\prime}$ eutectic is observed. The same type of carbides occurs in all zones, they are mainly tungsten and titanium MC type carbides, in some places combined with $M_{23} C_{6}$ type carbides. MC type carbides are located mainly in the interdendritic spaces and partly inside and at the grain boundaries. On the other hand, the $M_{23} C_{6}$ type carbides are released mainly at the grain boundaries. Carbides have various shapes, from globular / equiaxed, through compact and irregular shaped down to coniferous (fig. 7).

Often, the most important microstructural factors responsible for the final fatigue properties of the product are invisible to the naked eye. The microstructure can be important in assessing the performance of the part. The primary precipitation of carbides is one of the most important factor influencing the fatigue 
properties of the final material. In the case of high accumulation of the described carbides in the microstructure of nickel superalloy, low strength properties of the material are obtained. Casting superalloys containing a lot of primary carbides show relatively low fracture toughness, especially in areas of high chemical segregation. When high temperature is used, the so-called carbides are released in the superalloy structure. Chinese script morphology precipitates were visible very clearly (fig. 6). This type of carbides and a large number of carbides are shown in figure 5 - melt number 3 .
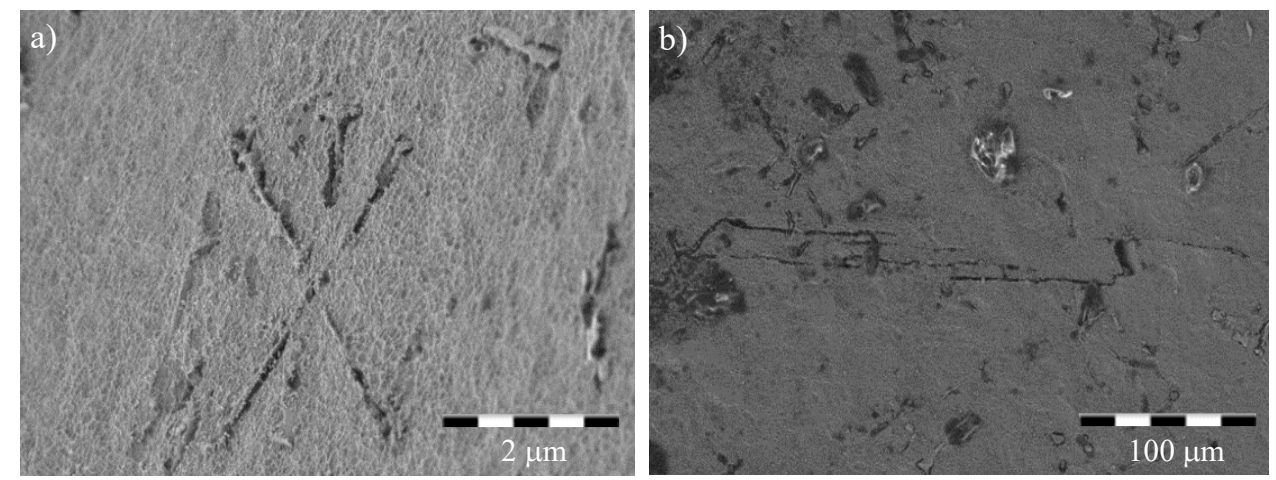

Fig. 6. Microstructure of the ŻS6U-WI alloy in the zone of the right corner of the smelt No. 3. Visible precipitations of $\mathrm{MC}$ and $M_{23} C_{6}$ carbides, etched state, Killing reagent. SEM: a) "Chinese script" type carbides, b) fatigue crack of the compressor turbine blade
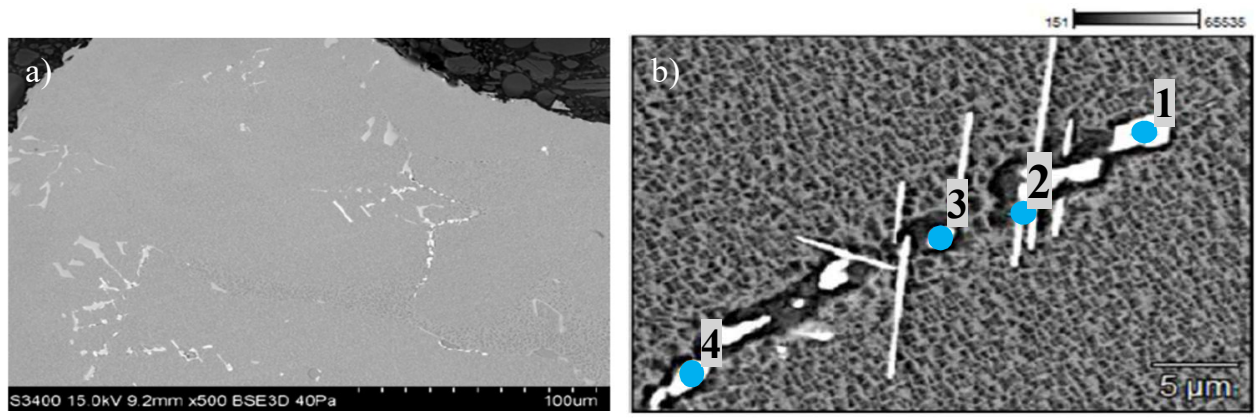

Fig. 7. Microstructure of the ŻS6U-Wi alloy for heel number 3. Visible precipitations of MC and $M_{23} C_{6}$ carbides in interdendritic spaces and inside dendrites, etched state, Kalling's reagent, SEM: a) $\mathrm{MC}$ and $M_{23} C_{6}$ carbides, b) carbides - chemical composition analysis

Figures 3 to 6 show that large differences in the microstructure of the material can be obtained, affecting negatively the fatigue properties of the finished product. The casting temperature significantly influences the deterioration of the fatigue properties of the material because it affects the grain size, the number of carbide precipitates and the microstructure. Figure 3 shows that when the temperature of $1564^{\circ} \mathrm{C}$ was used, a large segregation of carbides occurred, which had a negative 
impact on the result of fatigue properties of aviation products. The castings produced at the temperature of 1535-1536 did not show any significant changes in the microstructure (Figures 3 and 4). The chemical composition of carbides is presented in Table 3.

In this study, carbides studies were conducted using SEM aided by EDS analysis. Several of the precipitates were examined by semi-quantitative analyses (Fig. 7b) which revealed the presence of M23C6 type carbides formed by/composed of tungsten and chromium.

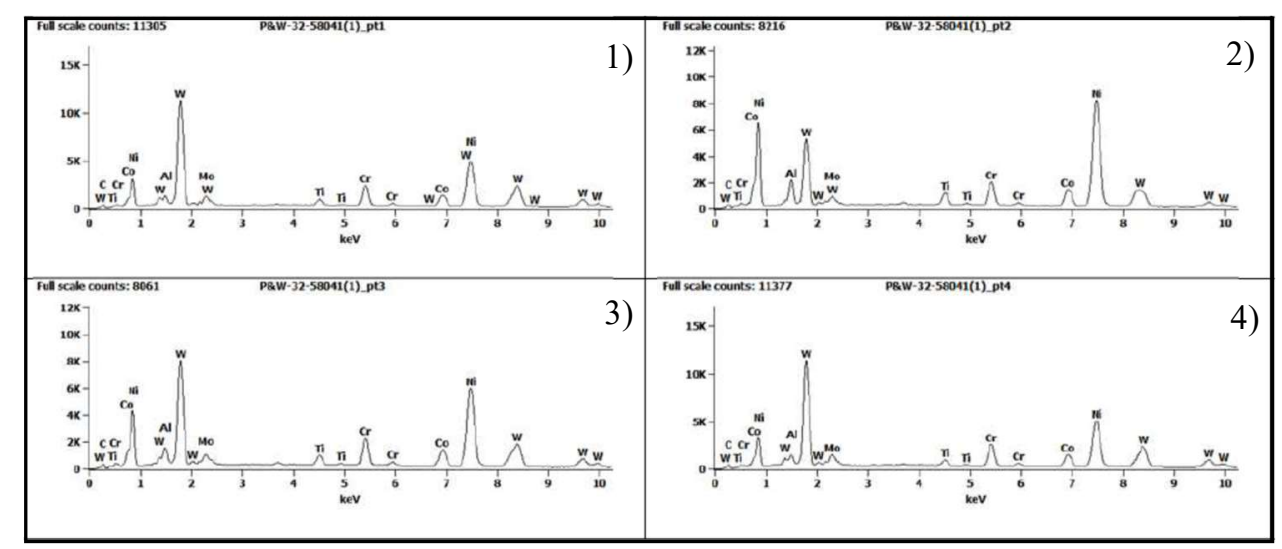

Fig. 8. Chemical composition of irregularly shaped carbides - melt number 3.

Table 4. Chemical composition of carbides [Weight\%] - melt number 3.

\begin{tabular}{|c|c|c|c|c|c|c|c|}
\hline \multicolumn{8}{|c|}{ Atom \% } \\
\hline & Al-K & Ti-K & Cr-K & Co-K & Ni-K & Mo-L & W-L \\
\hline 1 & 6,0 & 3,6 & 13,2 & 9,4 & 40,4 & 3,9 & 23,6 \\
\hline 2 & 12,1 & 3,7 & 8,0 & 8,3 & 56,8 & 1,5 & 9,6 \\
\hline 3 & 8,5 & 3,5 & 11,3 & 8,8 & 47,7 & 2,8 & 17,4 \\
\hline 4 & 6,6 & 3,1 & 13,3 & 9,5 & 40,6 & 4,7 & 22,2 \\
\hline \multicolumn{8}{|c|}{ Weight \% } \\
\hline & Al-K & Ti-K & $\mathrm{Cr}-\mathrm{K}$ & Co-K & Ni-K & Mo-L & W-L \\
\hline 1 & 1,9 & 2,0 & 7,9 & 6,4 & 27,4 & 4,3 & 50,1 \\
\hline 2 & 4,9 & 2,7 & 6,2 & 7,3 & 50,1 & 2,1 & 26,5 \\
\hline 3 & 2,9 & 2,2 & 7,5 & 6,7 & 36,1 & 3,5 & 41,1 \\
\hline 4 & 2,1 & 1,7 & 8,1 & 6,6 & 28,0 & 5,3 & 48,1 \\
\hline
\end{tabular}




\section{Research on fatigue properties}

The average fatigue strength of the tested blades (melt number 1) is $34,8 \mathrm{kG} / \mathbf{m m}^{2}$, standard deviation $\mathrm{s}=3,53 \mathrm{kG} / \mathbf{m m}^{2}$.

Table 5. The course of fatigue strength tests of the Compressor Turbine Blades. Melt 1.

\begin{tabular}{|c|c|c|c|c|c|}
\hline $\begin{array}{l}\text { Blade } \\
\text { number }\end{array}$ & Test stress $\left[\mathrm{kG} / \mathrm{mm}^{2}\right]$ & $\begin{array}{c}\text { Breaking } \\
\text { stress } \\
{\left[\mathrm{kG} / \mathrm{mm}^{2}\right]}\end{array}$ & $\begin{array}{l}\text { Contractual } \\
\text { fatigue } \\
\text { strength limit } \\
{\left[\mathrm{kG} / \mathrm{mm}^{2}\right]}\end{array}$ & $\begin{array}{l}\text { Average } \\
\text { fatigue } \\
\text { strength } \\
{\left[\mathrm{kG} / \mathrm{mm}^{2}\right]}\end{array}$ & $\begin{array}{l}\text { Standard } \\
\text { deviation } \\
{\left[\mathrm{kG} / \mathrm{mm}^{2}\right]}\end{array}$ \\
\hline $\mathrm{P} 1$ & $22,24,26,28,30,32,34$ & 34 & 33 & \multirow{9}{*}{34,8} & \multirow{9}{*}{3,53} \\
\hline P2 & $22,24,26,28,30,32,34,36$ & 36 & 35 & & \\
\hline P3 & $26,28,30,32,34$ & 34 & 33 & & \\
\hline P4 & $26,28,30,32$ & 32 & 31 & & \\
\hline P5 & $26,28,30,32,34,36,38$ & 38 & 37 & & \\
\hline P6 & $26,28,30, \ldots 42,44$ & 44 & 43 & & \\
\hline P7 & $26,28,30,32,34,36$ & 36 & 35 & & \\
\hline P8 & $26,28,30,32,34$ & 34 & 33 & & \\
\hline P9 & $26,28,30,32,34$ & 34 & 33 & & \\
\hline
\end{tabular}

The average fatigue strength of the tested blades (melt number 2) is $32,3 \mathrm{kG} / \mathrm{mm}^{2}$, standard deviation $\mathrm{s}=2 \mathrm{kG} / \mathrm{mm}^{2}$.

Table 6. The course of testing the fatigue strength of the Compressor Turbine blades. Melt 2.

\begin{tabular}{|c|c|c|c|c|c|}
\hline $\begin{array}{l}\text { Blade } \\
\text { number }\end{array}$ & Test stress $\left[\mathrm{kG} / \mathrm{mm}^{2}\right]$ & $\begin{array}{c}\text { Breaking } \\
\text { stress } \\
{\left[\mathrm{kG} / \mathrm{mm}^{2}\right]}\end{array}$ & $\begin{array}{l}\text { Contractual } \\
\text { fatigue strength } \\
\text { limit }\left[\mathrm{kG} / \mathrm{mm}^{2}\right]\end{array}$ & $\begin{array}{l}\text { Average } \\
\text { fatigue } \\
\text { strength } \\
{\left[\mathrm{kG} / \mathrm{mm}^{2}\right]}\end{array}$ & $\begin{array}{l}\text { Standard } \\
\text { deviation } \\
{\left[\mathrm{kG} / \mathrm{mm}^{2}\right]}\end{array}$ \\
\hline $\mathrm{P} 1$ & $22,24,26,28,30,32,34$ & 34 & 33 & \multirow{9}{*}{32,3} & \multirow{9}{*}{2} \\
\hline $\mathrm{P} 2$ & $26,28,30,32$ & 32 & 31 & & \\
\hline P3 & $26,28,30,32,34,36$ & 36 & 35 & & \\
\hline P4 & $26,28,30,32$ & 32 & 31 & & \\
\hline P5 & $26,28,30$ & 30 & 29 & & \\
\hline P6 & $26,28,30,32,34$ & 34 & 33 & & \\
\hline P7 & $26,28,30,32$ & 32 & 31 & & \\
\hline P8 & $26,28,30,32,34,36$ & 36 & 35 & & \\
\hline P9 & $26,28,30,32,34$ & 34 & 33 & & \\
\hline
\end{tabular}


The average fatigue strength of the tested blades (melt number 3) is $19,7 \mathbf{~ k G} / \mathbf{m m}^{2}$, standard deviation $\mathrm{s}=2,24 \mathrm{kG} / \mathrm{mm}^{2}$.

Table 7. The course of testing the fatigue strength of the Compressor Turbine blades. Melt 3.

\begin{tabular}{|c|c|c|c|c|c|}
\hline $\begin{array}{l}\text { Blade } \\
\text { number }\end{array}$ & Test stress $\left[\mathrm{kG} / \mathrm{mm}^{2}\right]$ & $\begin{array}{c}\text { Breaking } \\
\text { stress } \\
{\left[\mathrm{kG} / \mathrm{mm}^{2}\right]}\end{array}$ & $\begin{array}{l}\text { Contractual } \\
\text { fatigue } \\
\text { strength limit } \\
{\left[\mathrm{kG} / \mathrm{mm}^{2}\right]}\end{array}$ & $\begin{array}{l}\text { Average } \\
\text { fatigue } \\
\text { strength } \\
{\left[\mathrm{kG} / \mathrm{mm}^{2}\right]}\end{array}$ & $\begin{array}{l}\text { Standard } \\
\text { deviation } \\
{\left[\mathrm{kG} / \mathrm{mm}^{2}\right]}\end{array}$ \\
\hline P1 & 22 & 22 & 21 & \multirow{9}{*}{19,7} & \multirow{9}{*}{2,24} \\
\hline $\mathrm{P} 2$ & 18 & 18 & 17 & & \\
\hline P3 & $18,20,22,24$ & 24 & 23 & & \\
\hline P4 & $18,20,22$ & 22 & 21 & & \\
\hline P5 & $18,20,22$ & 22 & 21 & & \\
\hline P6 & 18 & 18 & 17 & & \\
\hline P7 & $18,20,22$ & 22 & 21 & & \\
\hline P8 & 18 & 18 & 17 & & \\
\hline P9 & 18,20 & 20 & 19 & & \\
\hline
\end{tabular}

\section{Średnia wytrzymałość zmęczeniowa [kG/mm²]}

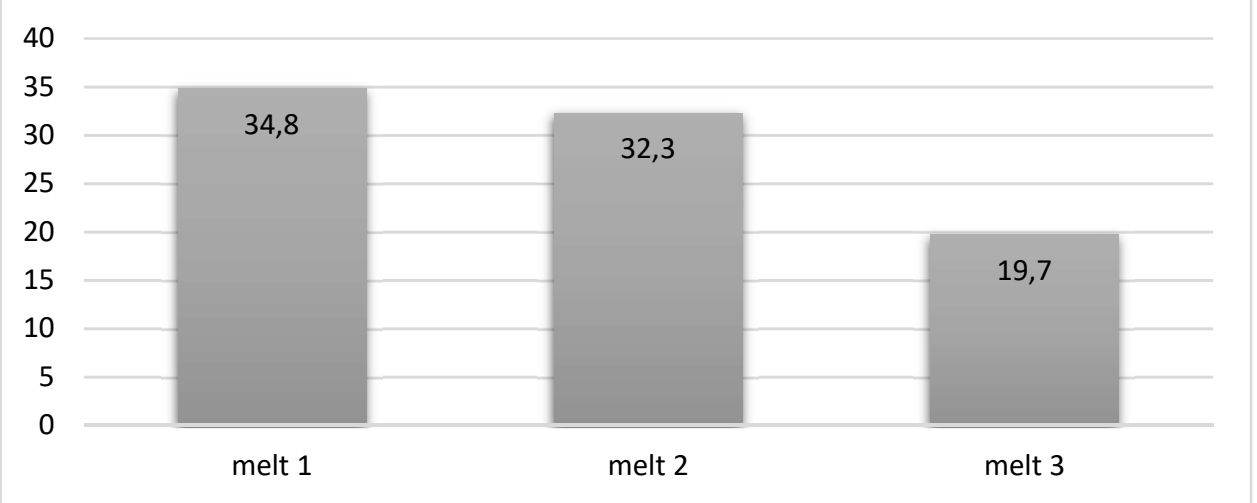

Fig. 9. Average fatigue strength results for heats number 1, 2 and 3.

\section{Summary}

Based on the conducted research, it can be concluded that:

- Metallographic tests and general observations of the microstructure allowed to determine typical microstructure constituents of the nickel alloy of the ŻS6U-WI grade. It consists of the y phase, i.e. a solid solution of alloying elements in nickel (matrix), the intermetallic compound $\mathrm{y}^{\prime}-\mathrm{Ni}_{3}(\mathrm{Al}, \mathrm{Ti})$ playing a strengthening role in the alloy and carbides of 
the $\mathrm{MC}$ and $M_{23} C_{6}$ types, the presence of eutectic is also occasionally observed y-y'.

- No differences were observed between heats 1 and heats 2 . The microstructure of the described heats 1 and 2, taking into account the criterion of the morphology of the phase components (shape, size and distribution of the strengthening phase particles and carbides in the melt) is homogeneous and does not show significant differences depending on the zone studied cross section.

- Differences in the microstructure between the heats 1,2 and the heel No. 3 were observed. In the microstructure of the melt No. 3, a significant amount of precipitation of MC type carbides with coniferous, uneven shapes was observed. Precipitations of carbides, referred to in the literature as "Chinese script", were observed.

- Significant differences in fatigue strength were observed between melts $1 / 2$ and melt 3 . Heats cast at $1535 \div 1536^{\circ} \mathrm{C}$ showed an average fatigue strength of $32.3 \div 34.8 \mathrm{kG} / \mathrm{mm}^{2}$. On the other hand, the average fatigue strength of the tested blades from melt number 3 is $19.7 \mathrm{kG} / \mathrm{mm}^{2}$ standard deviation $\mathrm{s}=2,24 \mathrm{kG} / \mathrm{mm}^{2}$ (melt number 3 is cast at $1564^{\circ} \mathrm{C}$ ).

- A correlation was observed between the casting temperature, the alloy microstructure and the fatigue strength of the finished product. In the case of using high casting temperature, numerous primary MC type carbides with irregular and coniferous shapes were separated, which was reflected in the fatigue strength of $19,7 \mathrm{kG} / \mathrm{mm}^{2}$.

\section{Bibliography}

[1] Ulewicz R.: Influence of selected technological factors on fatigue strength. Technical Transations, Mechanics, 3-M/2016.

[2] Przeliorz R., Piątkowski J.: Application of DSC Method in Studies on Phase Transitions of Ni Superalloys. Archives of foundry engineering. Volume 17. Issue 4/2017, 133-136.

[3] Golewski P.: Obciążenia cieplno-mechaniczne łopatek silników turbinowych z ceramicznymi powłokami ochronnymi. Rozprawa doktorska. Lublin 2015.

[4] Pytel M., Nowotnik A., Szeliga D., Sieniawski J.: Microstructural investigations of nickelbased superalloys with different structure. Key Engineering Materials Vols 592-593 (2014) p. 557-560.

[5] Nowotnik A., Rokicki P., Pędrak P., Kotowski S., Sieniawski J., Mrówka-Nowotnik G. (2013). Mechanical Aspects of Plastic Deformation of Nickel Based Superalloy. Key Engineering Materials, 592-593, 724-727.

[6] Bylica Z., Raczyński J., Marszałek Z., Opiekun A., Siwy S.: Badania struktury i własności mechanicznych stopów na osnowie niklu stosowanych do produkcji łopatek i dysków turbin gazowych. Luty 1975, doc. A. M.

[7] Pirowski Z., Uhl W., Wodnicki J., Gwiżdż A., Jaśkowiec K.: Effect of heat treatment on structure of the Inconel 740 type alloy. Praca instytutu odlewnictwa, Tom LI, 2011, zeszyt 2. 
[8] Nowotnik A., Rokicki P., Mrówka-Nowotnik G., Sieniawski J. (2015). Dynamic precipitation of nickel-based superalloys undergoing severe deformation below the solves temperature. International Journal of Materials Research, 106(7), 665-675.

[9] Salvati E., Nowell D., Korsunsky A.M., Silca F., Tai Y.H.: The effect of surface damage and residual stresses on the fatigue life of nickel superalloys at high temperature, International Jurnal of Fatigue, R. MN Fleury, Tom 119, luty 2019.

[10] Cieśla M.: Cracking processes and durability of ŻS6U nickel alloy with aluminide coatings in the conditions of accelerated creep at a temperature of $950^{\circ} \mathrm{C}$. Inżynieria Materiałowa, 2008, Vol. 29, nr 6, 936-944.

[11] Gawroński Z., Łażewski R.: Wpływ synergizmu obróbki cieplno-chemicznej i ubytkowej na wytrzymałość zmęczeniową stykową rolek łożyskowych. Inżynieria Materiałowa, nr 4/2011, 40.

http://dx.doi.org/10.7862/rm.2021.05 